特 集

\title{
最新放射線化学（応用編）
}

\section{9 放射線グラフト重合法による高度分離材料の開発}

\author{
斎藤恭一 $^{\dagger}$ \\ 千葉大学大学院工学研究科 \\ 263-8522 千葉市稲毛区弥生町1-33 \\ ${ }^{\dagger}$ marukyo@faculty.chiba-u.jp
}

\begin{abstract}
放射線グラフト重合及び後続の化学反応によって, 市販の 6-ナイロン繊維に付与したグラフト 鎖相に，不溶性無機化合物，抽出試薬，及び䤉素を固定した。不溶性フェロシアン化コバルトを 担持した繊維が, 東京電力福島第一原子力発電所の污染水からの放射性セシウムの除去に使用さ れている。酸性抽出試薬担持繊維及びウレアーゼ固定繊維は, それぞれ酸性溶液からの希土類イ オンの回収及び水中の尿素の加水分解に適用可能であった。
\end{abstract}

Key Words: polymeric adsorbent, radiation-induced graft polymerization, caesium-ion removal, rare-earth metal ion recovery, urea hydrolysis

\section{1. はじめに}

高分子基材に放射線を照射してラジカルを 発生させ, そのラジカルを開始点（固定端）と して機能を付与するための高分子鎖を接ぎ木す る方法が放射線グラフト重合法である。放射線 グラフト重合法は, 基材の材質や形状を広い範 囲で選べる点から, 強力な高分子修飾法の一つ である。基材の材質と形状の組み合わせとし て，ポリエチレン（PE）製非多孔性フィルム, ポリエチレンテレフタレート (PET) とPEの 芯鞘構造の不織布, PE製多孔性中空糸膜, 6ナイロン製繊維などがある。この組み合わせの なかから, ボタン電池用隔膜, 塩基性ガス吸着 用不織布, タンパク質除去用中空糸型アニオン 交換吸着膜, そして放射性セシウム除去用吸着 繊維が実用化されている ${ }^{1)}$ 。

これまでは, 用途に適した形状をもつ基材 に付与したグラフト鎖に, イオン交換基やキ レート形成基といった官能基を導入して金属イ オンやタンパク質を捕捉する機能を与えてき た。ここ10年間のうちに, 新しい用途や高い
性能への要求に対応するために, 固定端から自 由端まで，ある程度の長さをもつグラフト鎖が 作る空間に酵素, 抽出試薬, 及び無機化合物を 固定（担持とも呼ぶ）する研究が進んだ。これ は分離や反応へのグラフト鎖の寄与がより間接 的になり，グラフト鎖は主役から脇役へ転じた ように見える。しかしながら，プラズマや薬品 などによって高分子基材にラジカルを発生させ る他のグラフト重合法では作製が難しい材料を 提供できていることから放射性グラフト重合に よって付与したグラフト鎖の利用が深化したと 言える。

本稿では, 市販の6-ナイロン繊維（以後, ナ イロン繊維）を高分子基材を使い，放射線グラ フト重合法, なかでも前照射グラフト重合法 を適用して作製したつぎの3つの用途向けの材 料の物性や性能を解説する。(1) 污染水中から 放射性セシウムを除去する無機化合物担持繊 維, (2) 磁石切削粉の酸溶解液中からレアアー スを捕捉する抽出試薬担持繊維, 及び(3) 超純 水中の尿素を分解する酵素固定繊維。基材と してナイロン繊維を選んだ理由は次の 3 点で 
ある。（1）径の小さいビーズ状吸着材をつなげ て作ったのが吸着繊維であるとみなせるので, 外部接触面積が大きく, 捕捉対象成分の内部 拡散物質移動抵抗が小さい吸着材を作製でき る, (2) 吸着材の使用現場の状況に合わせて, 吸着繊維を適当な集合体に成型できる。例え ば，組み紐状にして污染海水に直接投入，その 後に容易に回収できる ${ }^{2)}$ 。また, 吸着繊維から フィルターを作ってポンプを使って液を流通さ せることができる，及び(3) ボビンの形状で吸 着繊維を量産できる。

\section{2. 污染水処理への応用：無機化合物を担持し たグラフト鎖からなる『新しい吸着場』}

東京電力福島第一原子力発電所では 2011 年

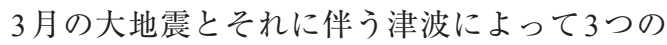
原子炬がメルトダウン事故を起こした。その 後, 污染水が大量に発生した。そのために, 放 射性のセシウム（例えば， ${ }^{137} \mathrm{Cs}$ ），ストロンチ ウム（例えば, ${ }^{90} \mathrm{Sr}$ ) で代表される放射性物質 の污染水からの除去が必要になった。発電所内
の排水路を流れる污染水や原子炉建屋から漏出 した污染水が加わった海水から放射性セシウム を除去するには，粒子あるいはビーズ状の吸着 材よりも，污染水に直接に投入できる繊維状の 吸着材が適している ${ }^{3)}$ 。そこで，まず，放射線 グラフト重合法によって，ナイロン繊維にエポ キシ基をもつビニルモノマー（グリシジルメタ クリレート，GMA）をグラフト重合したのち, トリエチレンジアミンを反応させてアニオン交 換基をグラフト鎖に導入した。つぎに，フェロ シアン化物イオン $\left(\mathrm{Fe}(\mathrm{CN})_{6}^{4-}\right)$ をグラフト鎖 に固定し，さらに，コバルトイオン $\left(\mathrm{Co}^{2+}\right)$ と の沈殿生成反応によってフェロシアン化コバル トをグラフト鎖内に析出させた（図1の(a)）。

得られたフェロシアン化コバルト担持繊維 の断面の元素分布をSEM-EDX（エネルギー分 散型 X線分光法）によって調べた（図2）。繊維 の周縁部にフェロシアン化コバルトが析出担持 されることがわかった。フェロシアン化コバル トがグラフト鎖から久落せずに安定して担持さ れている理由は, 析出物の表面電荷がマイナス

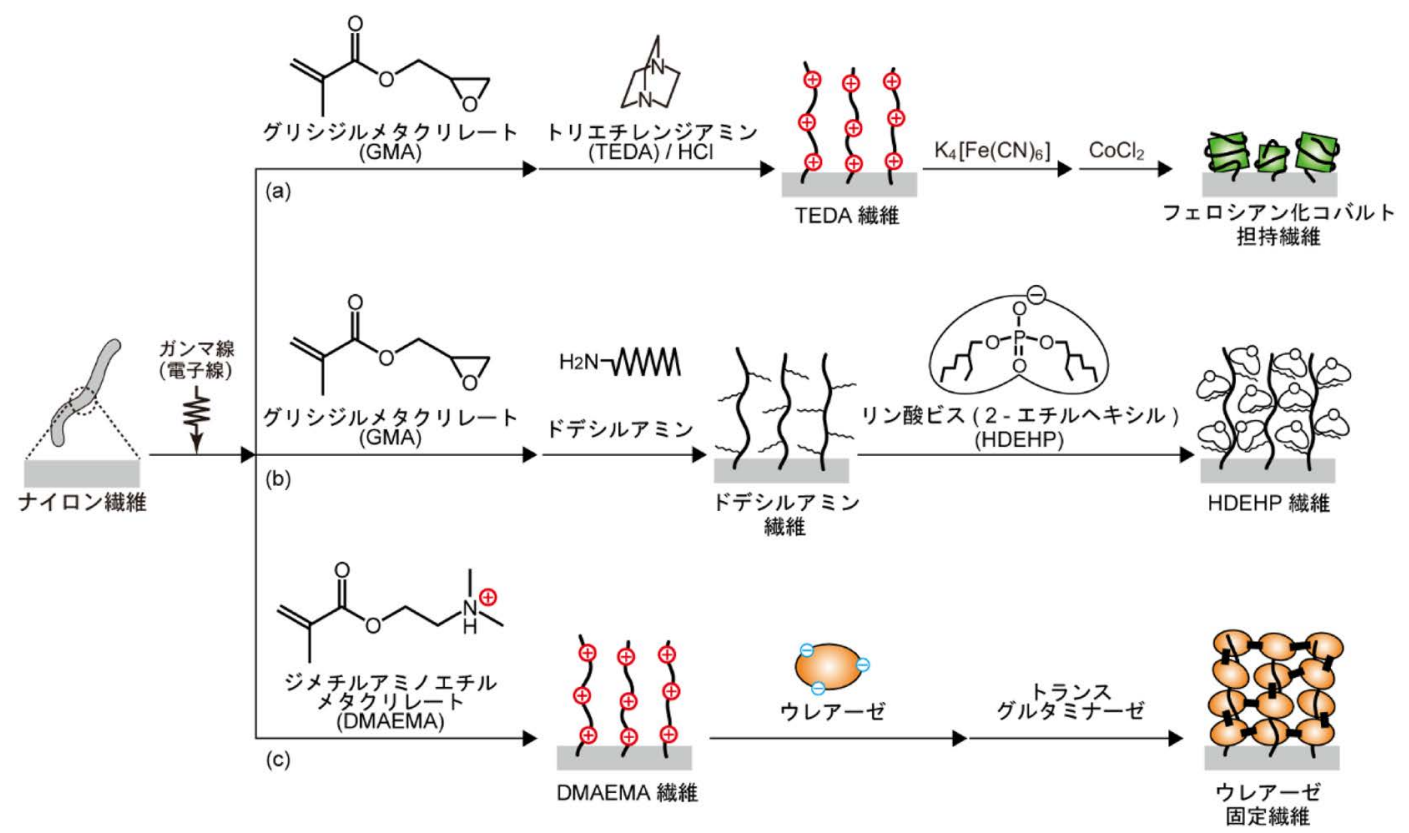

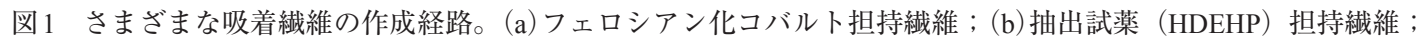
(c)ウレアーゼ固定纎維（Color online） 
であるため, グラフト鎖のプラス電荷（アニオ ン交換基）と引き合い，析出物がグラフト鎖に 巻き絡んで固定されているからである ${ }^{4)}$ 。アニ オン交換グラフト鎖相が無機化合物の析出と固 定に適した場を与えている。

1 回の反応で $100 \mathrm{~kg}$ の量の吸着繊維を生産で きる反応装置が設計運転されている。この吸着 繊維は組み紐に成型され，東電福島第一原発の 污染水処理に利用されている（図3）。フェロ シアン化コバルトを除いた高分子部分はすべて 焼却できるため, 放射性セシウムを吸着後に吸 着繊維を焼却減容できる。焼却後に残った無機 分を放射性廃棄物として容器に保管・管理すれ ばよい。

\section{3. レアアース回収への応用：抽出試薬を担持}

\section{したグラフト鎖からなる『新しい抽出場』}

ネオジム磁石は鉄, ホウ素, ネオジム $(\mathrm{Nd})$, 及びディスプロシウム（Dy）という4つの元素 からなる。この磁石を切削してさまざまなサイ ズや形状の磁石を成型する作業で発生する切削 粉の中にNdとDyが含まれる。それをいったん 酸に溶かして水相とし, $\mathrm{Nd}$ とyを精製するこ

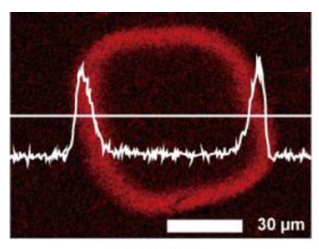

(a) Co

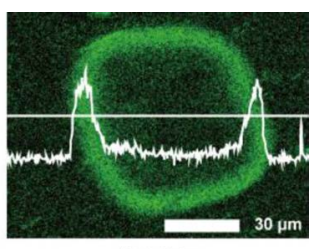

(b) $\mathrm{Fe}$
図2 フェロシアン化コバルト担持繊維断面の元素分 布 (Color online)

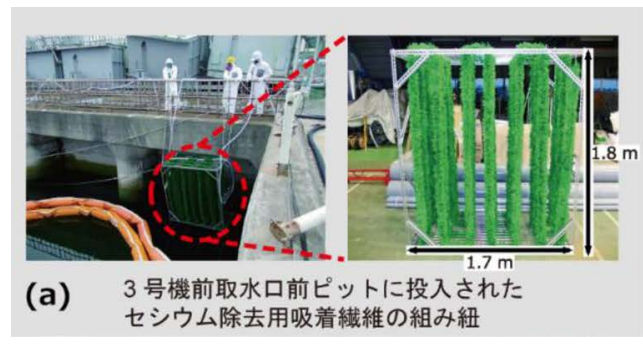

図3 東電福島第一原発で利用されているセシウム除去用吸着繊維の組み紐（Color online）

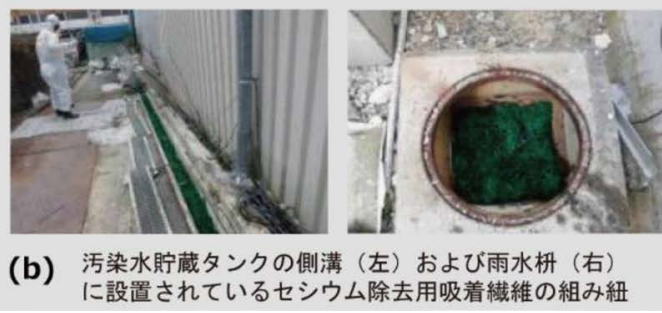

(b) 污染水貯蔵タンクの側溝（左）および雨水杵（右）
とが必要である。現状では, 抽出試薬を有機 溶媒に溶かして油相とし，水相から NdとDyを 抽出している。有機溶媒の使用をなくすために も, 抽出試薬の水相へのロスを減らすために も, 抽出試薬を繊維に固定することが有効であ る。

抽出試薬（HDEHP, リン酸水素ビス-2-エチ ルヘキシル）は，リン酸基の左右対称に炭素数 6 （分岐部を除く）の疎水性基を有する構造を もっている。それを高分子鎖に固定するため に，まず，放射線グラフト重合法によって，エ ポキシ基をもつビニルモノマー（GMA）をナ イロン繊維に接ぎ木した。つぎに，グラフト鎖 中のエポキシ基とドデシルアミン $\left(\mathrm{C}_{12} \mathrm{H}_{25} \mathrm{NH}_{2}\right)$ を反応させて疎水性基（ドデシル基）をグラフ ト鎖に導入した。さらに，このドデシル基と抽 出試薬の疎水性部との疎水性相互作用によっ て抽出試薬をグラフト鎖に担持した（図1の (b))。

得られた抽出試薬担持繊維 (HDEHP繊維と 呼ぶ）の HDEHP担持密度は $0.43 \mathrm{~mol} / \mathrm{kg}$-product であった。HDEHP瀻維をカラムに充填し，一 定量の Dyと Ndイオンを繊維に吸着させた後, 濃度の異なる 3 種類（0.2, 0.3 , 及び $1.5 \mathrm{M})$ の 塩酸を流通させて溶離させたときのクロマトグ ラムを図4に示す5)。吸着していた NdとDyを 分離してすべて溶離でき, しかも抽出試薬の水 相へのロスは無視できることがわかった。これ は疎水性基をもつグラフト鎖が有機溶媒の役割

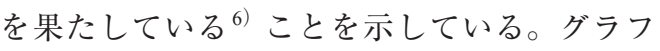
卜鎖に疎水性基を導入して形成されるグラフト 


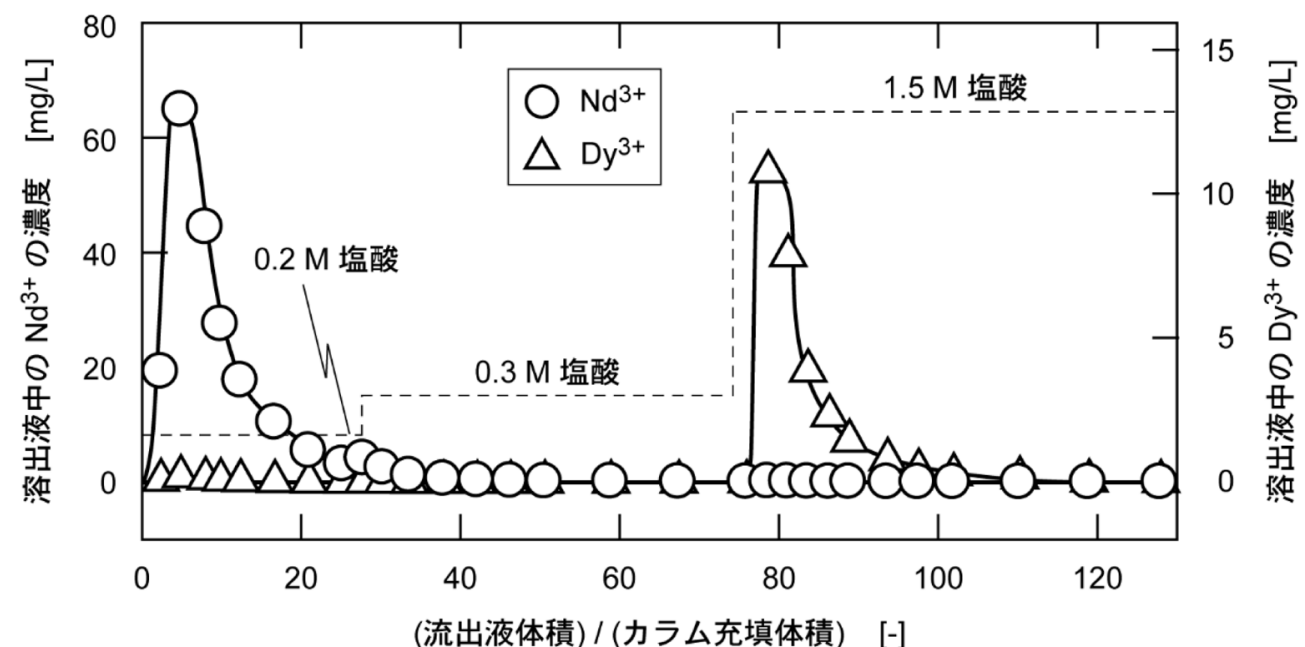

図4 HDEHP担持繊維充填カラムを使う Dyと Ndの溶出クロマトグラム

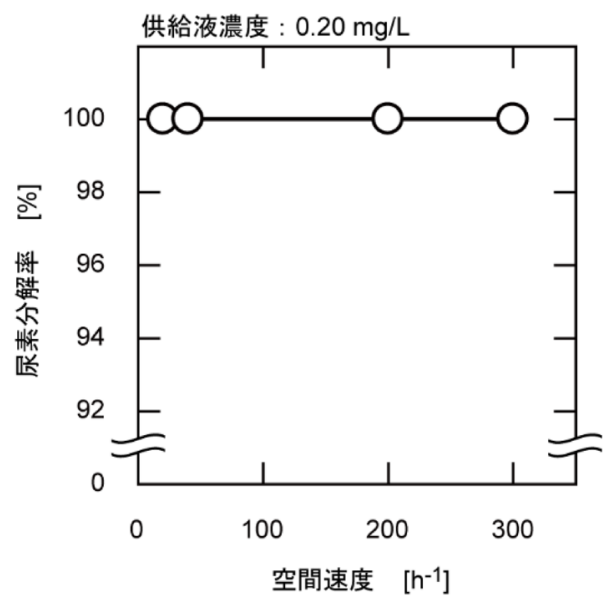

図 5 ウレアーゼ固定繊維充填カラムでの尿素分解率 と尿素溶液の空間速度との関係

鎖相に抽出試薬を安定担持できたことによっ て, 今後, 工業規模での固相抽出法の検討が進 むだろう。

\section{4. 超純水製造への応用：酵素を固定したグラ フト鎖からなる『新しい反応場』}

集積回路製造工場では回路表面のさまざま な化学処理後の洗浄のために大量の超純水を 使用している。超純水の水質が製品の歩留ま りを決めるので，水質の向上が必須である。 極微量ながら超純水に溶けている有機化合物
の中で, 電気的に中性で分子量の小さい尿素 $\left(\mathrm{NH}_{2} \mathrm{CONH}_{2}\right.$ ，分子量 60）の除去がこれまで課 題となってきた。このため, 尿素を尿素分解酵 素ウレアーゼによって分解してアンモニウム イオン $\left(\mathrm{NH}_{4}^{+}\right)$と炭酸ガスにしてから，イオン 交換と脱気の操作で除去することが解決策の一 つである。そこで，放射線グラフト重合法を採 用して，まず，ナイロン繊維にアニオン交換基 (ジメチルアミノ基, $\left.-\mathrm{N}\left(\mathrm{CH}_{3}\right)_{2}\right)$ をもつビニル モノマー（ジメチルアミノエチルメタクリレー ト）をグラフト重合した。つぎに，静電相互作 用によってウレアーゼをグラフト鎖に固定した (図1の (c))。

得られたウレアーゼ固定繊維のウレアーゼ 固定密度は $41 \mathrm{~g} / \mathrm{kg}$-productであった。この繊維 をカラムに充填し, 空間速度 $20 \sim 300 \mathrm{~h}^{-1}$ の範 囲で尿素水溶液を流通させた。ここで, 空間速 度は流量を充填体積で割った值で定義される。 尿素の分解率と空間速度との関係を図5 に示 す。実用の空間速度の範囲で $100 \%$ の分解率を 示した7)。

超純水中に溶存する微量の過酸化水素につ いても，ペルオキシダーゼを固定した繊維を， 上記と同様の経路で作製し, 水中の過酸化水素 を水と酸素に分解できることが実証されてい 
る ${ }^{8)}$ 。荷電基をもつグラフト鎖が伸長すること によって形成されるグラフト鎖相に, タンパク 質（ここでは酵素）を多層すなわち高密度に固 定できることを利用して, 高活性な数種の酵素 固定材料が堤案されている1)。

\section{5. おわりに}

放射線グラフト重合法を適用してナイロン 繊維に接ぎ木した高分子鎖に，無機化合物，抽 出試薬, 及び酵素を高密度に集積させて新しい 分離・反応場を作り出した。まず, アニオン交 換グラフト鎖内で析出した不溶性フェロシアン 化コバルトはグラフト鎖との静電相互作用に よってグラフト鎖に絡むために安定して担持さ れた。つぎに，これまで有機溶媒に溶解して使 用されてきた抽出試薬が疎水性グラフト鎖に安 定に担持された。さらに，グラフト鎖中の荷電 基同士の反発によって伸長したグラフト鎖に酵 素を多層で集積させた後, 酵素間を架橋によっ て固定した。グラフト鎖に直接に官能基（イオ ン交換基やキレート形成基）を導入することに 代わって, 分離や反応に役立つ物質をグラフト 鎖相に取り込むことによって, グラフト材料の 新しい用途が開拓されつつある。

\section{文献}

1) 斎藤恭一, 藤原邦夫, 須郷高信, グラフト重合 による高分子吸着材革命，丸善，東京（2014）

2）斎藤恭一, Cs P $\mathrm{Sr}$ 高速で除去する繊維, 化 学, 67(11), 35-37 (2012)

3) 後藤聖太, 斎藤恭一, 東京電力福島第一原子力 発電所港湾内の污染海水から放射性物質を除去 する吸着繊維の開発 (1) 放射性セシウムの除去, RADIOISOTOPES, 65, 7-14 (2016)

4) Goto, S. Umino, S. Amakai, W. Fujiwara, K. Sugo, T. Kojima, T. Kawai-Noma, S. Umeno, D. and Saito, $\mathrm{K}$. Impregnation structure of cobalt ferrocyanide microparticles by the polymer chain grafted onto nylon fiber, J. Nucl. Sci. Technol., 53, 1251-1255 (2016)

5) 佐々木貴明, 内山翔一朗, 藤原邦夫, 須郷高 信, 梅野太輔, 斎藤恭一, リン酸ビス (2-エチ ルヘキシル）（HDEHP）担持充填纎維カラムを 用いた固相抽出法に基づく溶出クロマトグラ フィーによる $\mathrm{Nd}$ と $\mathrm{Dy}$ の分離, 化学工学論文 集, 41, 220-227（2015）

6) 佐々木貴明, 内山翔一朗, 藤原邦夫, 須郷高 信, 梅野太輔, 斎藤恭一, ドデシルアミノ基を 有するグラフト鎖上に担持した酸性抽出試薬り ン酸ビス（2-エチルヘキシル）（HDEHP）とド デカンに溶解したHDEHPのレアアース抽出で の類似性, 化学工学論文集, 40, 404-409 (2014)

7) Sugiyama, M., Ikeda, K., Umeno, D., Saito, K., Kikuchi, T. and Ando, K., Removal of urea from water using urease-immobilized fibers, J. Chem. Eng. Japan, 46, 509-513 (2013)

8) 川島 青, 杉山まい, 藤原邦夫, 須郷高信, 菊 池 隆, 小出富士夫, 狩野久直, 河合 (野間) 繁子, 梅野太輔, 斎藤恭一, 水中の過酸化水素 を高速分解するためのカタラーゼ固定繊維とパ ラジウム担持繊維の作製, RADIOISOTOPES, 64, 501-507（2015）

\section{Abstract}

\section{Modern Radiation Chemistry (Applications)}

19 Development of High-Performance Polymeric Adsorbents by Radiation-Induced Graft Polymerization

Kyoichi SAITo ${ }^{\dagger}$ : Chiba University, 1-33 Yayoi-machi, Inage-ku, Chiba Pref. 263-8522, Japan, †marukyo@faculty.chiba-u.jp

Insoluble inorganic compound, extractant, and enzyme were immobilized into the graft-chain phase formed onto a commercially available 6-nylon fiber by radiation-induced graft polymerization and subsequent chemical modifications. Insoluble cobalt ferrocyanide-impregnated fiber has removed radioactive caesium ions from water contaminated with radionuclides at TEPCO Fukushima Dai-ichi Nuclear Power Plant. Additionally, HDEHP-impregnated and urease-immobilized fibers were applicable to the recovery of rare-earth ions such as Nd and Dy in an acidic medium and the hydrolysis of urea in water, respectively. 